\title{
Editorial: The Rectification of Names
}

Joel Heng Hartse

Simon Fraser University, Canada

Sibo Chen

Simon Fraser University, Canada

Marie-Josée Goulet

Université du Québec en Outaouais, Canada

"If names be not correct, language is not in accordance with the truth of things"

名不正，则言不顺

- Confucian Analects

Welcome to the new issue of the Canadian Journal of Studies in Discourse and Writing/ Rédactologie. This issue marks several beginnings for the journal: there is a new editorial team; the journal's archives will soon be fully available online; and the journal has moved to an "issue-in-progress" model fitting the open access, online trend of academic publishing.

Due to these shifts, we thought it appropriate to introduce this new issue of the journal, which includes a special section on the future of writing centers in Canada guest-edited by Roger Graves, with a version of Confucius' "rectification of names". What do we mean by each of the words or phrases in the journal's title? How do they express the character of this publication and what we hope it will do in the future?

\section{Canadian}

What makes $C J S D W / R$ Canadian? The most obvious answer is that it is the official journal of a Canadian professional association, the Canadian Association for the Study of Discourse and Writing (CASDW). The journal has also been edited by scholars associated primarily with Canadian institutions. Because of its Canadian character, the journal is purposefully bilingual. This means we publish articles in both English and French; we also aim to have abstracts for each research article appearing in both languages, and have plans for a Frenchlanguage special section no later than 2018. 
Another way in which the Canadian character of the journal will manifest is in its openness and flexibility. We hope that in the articles we publish some arguably Canadian qualities will be displayed, such as a robust multiculturalism, an appreciation for both official bilingualism and on-the-ground multilingualism, an interest in and connection to international affairs (including, but not limited to, connections to other Anglophone and Francophone contexts) and a willingness to look beyond Canada's borders when we consider work that will be of interest to the journal's contributors and readers.

\section{Journal}

The landscape of scholarly publishing has experienced rapid changes since the previous incarnation of this journal, Technostyle, began publishing in 1982. Today, technology has made publishing easier and faster, and the open access movement has allowed scholarly journals to distribute their work more widely. In recent years, however, this journal has been published less frequently than it was when Technostyle was originally launched as a "thriceyearly" publication (Pavelich, 1982, p.1). The flexibility of online, open access publishing has led us to adopt what has been called an article-based or issue-in-progress model of publication. Rather than waiting until enough papers have been accepted to publish an issue, we will publish articles online as they are accepted for publication. This will allow more timely publication, which is beneficial to both contributors and the journal, and allow us to publish at least one issue per year regardless of how many submissions are accepted. This also gives us the freedom to create ongoing special issues, or what we have dubbed "special sections," that can be published simultaneously with regular issues.

\section{Studies}

$C J S D W / R$ (and Technostyle before it) has long been amenable to a variety of types of scholarly writing, including research articles, brief reports, historical studies, theoretical and conceptual essays, opinion pieces, book reviews, and responses to previously published work. This will continue to be the case. We anticipate that in the coming years, we will develop sections that encourage responses to items in previous issues as well as shorter articles that involve reports on research, events, and scholarly activities of interest to readers.

\section{Discourse and Writing}

$C J S D W / R$ inherits "discourse and writing" from CASDW, which defines itself as "a bilingual scholarly association dedicated to advancing the study and teaching of discourse, writing, 
and communication in academic and nonacademic settings-higher education, business, government, and nonprofit organizations" (CASDW-ACR, n.d.). Here, it seems that the "discourse and writing" label intends to accommodate a wide range of engagement with research inquiries related to written communication in academic and professional settings.

Yet, is it also possible to consider "discourse and writing" as a field of its own right in Canada? As Phelps (2014) pointed out in her keynote address during the 2012 CASDW conference, "discourse and writing studies in Canada are coalescing to form an inclusive academic identity that may be coming of age" (p. 4). Indeed, written communication-related research in Canada has been continuously struggling between the European socio-cultural tradition and the American pragmatic tradition. While such struggle has generated practical difficulty for assembling a single connected intellectual community among Canadian scholars, it also creates unique opportunities for interdisciplinary conversations and collaborations in the context of an increasingly multicultural and multilingual world. As such, by embracing the term "discourse and writing," $C J S D W / R$ aims to promote all approaches to writing and discourse research within the humanities and social sciences, as well as to further promote the development of this "inclusive academic identity."

\section{Rédactologie}

Dans la communauté scientifique francophone, le terme rédactologie désigne le champ de recherche interdisciplinaire ayant pour objet la rédaction. Pour certains, la rédactologie se concentre sur l'étude de la rédaction dans des situations professionnelles. Pour d'autres, elle englobe également l'étude de la rédaction en contexte académique ou scolaire. La rédactologie couvre tous les types de rédaction : générale, spécialisée, scientifique, technique, administrative, journalistique, imprimée, numérique, etc.

Comme son pendant anglophone, la rédactologie s'est façonnée en partie par l'emprunt de concepts et de méthodes provenant de plusieurs domaines, comme la linguistique, les communications, la psychologie cognitive et le design d'information, pour ne nommer que ces exemples. Les implications des recherches en rédactologie peuvent être théoriques, pratiques, pédagogiques, sociales, etc. En bref, $C J S D W / R$ adhère à une définition large de la rédactologie et souhaite publier des articles traitant de la rédaction dans divers contextes.

\section{Acknowledgement}

Getting the new version of $C J S D W / R$ off the ground has been an arduous undertaking, and we have benefitted from the help of many people. The previous editors of the journal, Jackie 
Rea and Katja Thieme, have been helpful and generous in transferring the journal's archives to the team at SFU, and members of the 2015-2016 Executive Committee of CASDW have been extremely supportive and offered wise advice as we begin the new phase of the journal. We are also grateful to Roger Graves for agreeing to edit our first special section and for his advice and mentorship.

We are grateful for the financial support of Simon Fraser University in the form of a University Publications Fund grant from the Office of Research Services and a Scholarly Digitization Fund grant from the SFU Library, and the support of SFU's Centre for English Language Learning, Teaching \& Research. We also appreciate Susmita Dey, Don Taylor, and Ian Song for their assistance in digitizing the journal's archives, and Kevin Stranack and James McGregor at the Public Knowledge Project for their advice and expertise. We would also like to welcome Monica Bhattacharjee as CJSDW/R's editorial assistant for 2016/2017.

CJSDW/R Editors

Joel Heng Hartse, Sibo Chen, \& Marie-Josée Goulet

\section{References}

CASDW-ACR (n.d.). Retrieved from https://casdw-acr.ca/

Pavelich, J. (1982). Editorial. Technostyle, 1(1), 1-2.

Phelps, L. W. (2014). The historical formation of academic identities: rhetoric and composition, discourse and writing. Canadian Journal for Studies of Discourse and Writing/Rédactologie, 25(1), 3-25. 